\title{
SKYSCRAPERS AND THE ECONOMY IN LATIN AMERICA
}

Nestor Garza*

Colin Lizieri**

\begin{abstract}
Skyscrapers are an intellectual challenge for urban analysis because of their imposing visual presence in the city landscape, and because of their environmental and real estate impacts. These characteristics however have not received too much attention in the literature, particularly in analyses about Latin American cities. In this paper we describe and test four theories about record breaking buildings height: traditional microeconomic theory, game theory, business cycle, and global cities. We use a 2000-2012 panel database of 29 cities from ten different Latin American countries, in order to contrast the contesting explanations about buildings' height. We design a baseline model and then, using four different estimation techniques and diverse specifications, find that the traditional theory and more strongly the global cities, are good predictors of buildings' height.
\end{abstract}

Keywords: urban economics; Latin America; skyscrapers; urban studies; global cities

* Instituto de Estudios Económicos del Caribe - Universidad del Norte. Barranquilla, Colombia.ng350@,uninorte.edu.co

** Grosvenor Professor of Real Estate Finance, Department of Land Economy, University of Cambridge.cml49@,cam.ac.uk 


\title{
SKYSCRAPERS AND THE ECONOMY IN LATIN AMERICA
}

\author{
Nestor Garza and Colin Lizieri
}

\section{INTRODUCTION}

Urban literature, particularly that on urban economics, does not frequently deal with skyscrapers, despite their imposing visual presence in contemporary city skylines. According to traditional microeconomic theory, building height increases as a function of the economic size of the cities where they are located. The largest economic agglomerations should have the highest land rents and the tallest built structures. The same theory states that land rents and building heights should be lower in cities that do not have geographical or legal limits to expansion.

However, traditional microeconomic theory has been criticized as inadequate for explaining the observed extreme heights of the tallest buildings in cities, when compared to other built structures, many of which seem to be poorly integrated into the urban fabric (Soares, 2010). We present three alternative theories on the factors driving skyscraper building: game theory approaches, the role of behaviour linked to business cycles, and the influence of globally integrated cities. Exploring the processes driving tall building development is important in understanding the dynamics of urban development, particularly in growing and emerging economies. Here, we focus on the tallest buildings in Latin American cities. Do the three alternative theories help explain building height and provide insights for investors, city planners and developers?

In this paper, we test these theories alone and in combination in a panel estimation context. A database with information on record breaking tall buildings in the period 2000-2012 in 29 cities from ten Latin American countries is assembled. Latin America is a highly populated (600 million inhabitants), and an extended (19 million square kilometres) emerging region and a growing target for global real estate investors seeking to diversify away from developed economies and gateway cities. It is relatively homogeneous from a cultural, institutional, and even planning practices point of view, when compared to other emerging macro-regions (such as South East Asia). This means that we can make country and city comparison that rely almost entirely on economic and/or geographic differences. 
The corresponding database is compiled from a range of websites and sources providing information about height, use, and location of buildings more than 100 metres tall in the region. The heights are regressed against city and national economic, social, and regulatory variables. This paper begins with this introduction, followed by a presentation of the competing theories in section 2. In section 3, we present the variables compiled in the database, set out their sources, discuss how they proxy the theories, and detail our empirical strategy. Section 4 presents regression results using four different panel estimation techniques, while in section 5 we discuss these results in the wider context of the contemporary Latin American urbanization. Conclusions are presented in the final section.

\section{FOUR COMPETING EXPLANATIONS FOR SKYSCRAPER HEIGHT}

\subsection{Traditional microeconomic models}

In standard, monocentric, urban spatial economic models of cities, firms add transport costs to their production costs in order to determine location ${ }^{1}$. These transport costs are a function of the distance to a pre-determined Central Business District (CBD). Any residual from these extractions is transferred to land rents and it determines optimal building height (Anas et al., 1998; Kraus, 2007) as firms and land-uses compete for scarce land in the city centre.

This theory predicts that economically larger cities should have taller buildings when compared with smaller ones. In turn, geographically extended cities (or those that are not too dense) should have lower buildings than those whose expansion is constrained, either by geographical or regulatory limits.

An empirical test of these hypotheses would require having information about the economic and geographic size of different cities, and their average structural heights. This last piece of information is very difficult to obtain for Latin American cities on any comparable basis, and it is almost impossible to obtain when individual metropolitan areas are considered.

In addition to the former, the other three theories to be presented below explicitly deal with the tallest building in a metropolitan area, as an ego-oriented or a seemingly irrational development construction project. This is why our focus is on the tallest building in each city-year observation

\footnotetext{
${ }^{1}$ And, in similar fashion, households' trade off space against commuting costs to the city centre, higher density of use (and hence building height) compensating for higher land costs in the centre.
} 
in our analysis, a type of information can be collected from a range of skyscrapers databases in public websites, which provide date of completion, building use and structural features including height. In the specific case of the traditional theory, in order to accept that the top height building proxies for the average structural height per $\mathrm{city}^{2}$, we must assume that the corresponding spatial differential land rents structure does not change with economic growth. In other words, that the city has a constant density/rent gradient, while its intercept increases with economic growth.

Regarding this assumption, many authors have found that the slope of the gradient requires periods of between 50-150 years to change, depending on the region and period of the study (McMillen, 2003; Malpezzi, 2006). In this paper we use information for a 12 year period, short enough to hold the assumption of a constant gradient slope, and consequently, top building heights increasing on a city GDP but decreasing on its Area.

Skyscrapers are highly influenced by urban regulation, not least because of their symbolic and environmental effects. In fact, in most cities highrises (here, defined as buildings more than 100 metres in height) require special permissions that have to be negotiated with the corresponding city planning authority (Sorensen, 2005; Bertaud and Brueckner, 2005; Ding, 2013; Cheshire and Derricks, 2014). This is why in the empirical analyses below we will include control variables that represent the effect of urban regulation.

\subsection{Two game theoretic approaches}

We have identified two linked but distinct game theoretic approaches to skyscrapers development in the urban economic literature, Helsley and Strange (H-S, 2008), and Barr (2013). We will first introduce the H-S game, as it better suits our inter-city panel estimation, and then, in a sub-section about empirics and critiques of $\mathrm{H}-\mathrm{S}$, we will present the approach by Barr.

The H-S game is a skyscraper race, similar to the patent race of industrial organization theory. It is similar because it is an 'all pay auction' where all of the contestants have to make the investments (in $\mathrm{R} \& \mathrm{D}$ or in height), even though they might not win the race. In the case of skyscrapers, the incentive to add height above the optimal comes from a 'prestige prize' that exactly offsets the losses/additional costs. In order to be $100 \%$ certain of being the tallest, a

\footnotetext{
2 That is, average building heights increase with maximum building height.
} 
player needs to spend additional resources that add extra costs to the construction project. The height that guarantees the exact equalization of profits + prestige prize, with the normal height costs + extra height costs is called the pre-emption height.

When using a mixed strategy solution of the H-S game, the pre-emption heights could be superior, equal or inferior to the optimal heights. As the players are playing simultaneously, they do not know the other players' chosen height and have to guess it by following a pre-defined probability function.

From this presentation of the H-S game we can extract two propositions:

- In order to be certain to win a skyscraper race, a contestant must over-build beyond optimal height and not just follow the urban economic fundamentals of economic and geographic size. It has to build to its pre-emption height.

- Even when pre-emption might guarantee winning the contest, long term economic growth will increase optimal height until the city catches-up with the building. Empirically speaking, the height premium is a time-moving target, and the observation of a longer period between record breaking building heights in a city would be an indicator of a more extreme overbuilding.

\section{Empirics and Critiques}

The H-S game was developed to deal with cases like the skyscraper race between the Chrysler Building and 40 Wall Street in New York in 1929-30, or the World Trade Centre of New York and the Sears Tower of Chicago in 1973-74. Jinhua et al (2008) state that a Bayesian approach to the probability of choices in the mixed strategies solution would allow the game to resemble not only some skyscraper race cases but, indeed, the entire heights from the building process in a city. These authors perform two independent analyses with 20 cities worldwide and 15 cities in the US, and they find that the H-S (2008) game is a better predictor of the top building height in a city than traditional urban economic theory.

Unfortunately, the Jinhua et al. (2008) analysis is largely exploratory, with an extremely endogenous regression variable (height of the previous top building), absence of a dynamic testing setting, and possibly, small sample bias. In the present paper, we will use panel estimation and instrumental variables, in order to differentiate strategic behaviour from time-moving and 
city-wide external determinants of heights. A different research strategy is followed by Koster, Ommeren and Rietveld (2013), who tried to detect agglomeration economies in the Netherlands, as evidenced in firms willing to pay $4 \%$ more for a building that is ten metres taller than others in the vicinity.

Barr (2010) criticizes the H-S game and proceeds to test a fully developed reduced form traditional microeconomics framework for New York in the period 1895-2004, where he rejects the prestige-game as the determinant of heights. However he does not focus on top (record breaking) building heights, as in the H-S model. It is interesting to note however, that in a different paper the same author (Barr, 2012) finds that prestige could be the reason for extraheights in certain areas of New York.

Barr (2013) constitutes a more immediate antecedent to this paper, as he develops a Cournotstyle game by dividing buildings' height demand into two sources: economy and prestige. The first is determined by traditional theory urban economy standards, but the second is determined by the other contestant's current record (strategic). Barr finds evidence of strategic behaviour with data for New York and Chicago during 1885-2007. In this paper we do not follow the Barr model directly, because we are interested in examining many cities simultaneously and focusing on pre-emption as in the H-S model, by using a time dimension.

\subsection{Business Cycle Behavioural Models}

In 1999, Andrew Lawrence introduced a Skyscraper Index, which was updated and analysed by Thornton (2005), who claimed it could be a predictor of the business cycle. According to this author, cyclical fluctuations of economic activity are dependent on human action, and it is impossible to determine the form and size of each cycle. However there are signals before economic downturns that can be perceived - and record breaking high buildings construction would be one of them. Thus the model links building height to over-investment at the peak of the business cycle.

Thornton finds that the completion of the world's record breaking buildings has coincided with global economic downturns $(1929,1974,1998$, and 2008). This does not mean that there is a causal relationship between height records and the cycle, but that the construction of new tallest skyscrapers occurs in contexts of over-investment and liquidity expansion. 
Despite these findings the index has not been adopted in the academic urban economics environment. This is because it does not offer a causal explanation for the phenomenon and ignores the microeconomic foundations of the field. There are resonances, however, to Marxian and critical urban social science ideas of over-accumulation in the built form of cities.

\section{Empirics and criticisms}

There is a relative lack of formal evidence in favour of this theory. A test performed by Barr et al (2015), found no evidence of Granger-causality from record breaker buildings to economic activity in the USA, China, Hong Kong and Canada. In contrast, Kaza (2010) uses what he calls corrected business cycle series per USA cities and finds positive evidence of the Thornton explanation.

Loffler (2013) uses a different approach, because he detects that US Stock returns may be predicted by construction starts of skyscrapers (high-rises more than 100 metres in the Emporis Database). This author considers that skyscrapers starts are a proxy for over-optimism, and consequently a predictor of stock exchange patterns ${ }^{3}$.

In the present paper, we will not explicitly test the existence of a causal relationship between skyscrapers starts and/or completions with income growth cycles but, rather, we will try to find an association between these variables per city in a panel estimation context, given the interest that has been expressed in the index by business analysts and other general audiences ${ }^{4}$ despite scarce academic interest in this business cycle explanation.

\subsection{Global Cities}

Following pioneering works by, inter alia, Sassen (1991) and Hall (1996), a vast literature exists on the concept of a global city. We can summarize this branch of research and indicate its relevance for this paper, by noting that globally-oriented leading economic sectors in the contemporary world economy are found to be concentrated in cities where the highly skilled labour required for these activities can be comfortably housed and, in turn, the concentration of advanced producer services attracts highly skilled, mobile labour. These forces of concentration have real estate implications.

\footnotetext{
${ }^{3}$ That is a finding in line with the ideas about cycles and construction expressed by Shiller (2005).

${ }^{4}$ Barclays Capital - Equity Research. Skyscraper Index: Bubble building. 10 January 2012.
} 
The global cities researchers have focused on economic and sociological aspects of these types of environments, but a systematic approach to spatial features has been relatively neglected. Thus Ford (1998) questioned why in the global cities literature there were no explicitly references to the type of built environment where the 'global' is being undertaken:

"The production of office, hotel, and retail space, however, is not the focus in most globalization literature. Authors deal primarily with capital flows, communication networks, and the total volume of business transactions, skating over any idea that businesses must be housed, for the most part, in increasingly sophisticated buildings. High-level decision making in the new global economy takes place in particular types of architectural settings, not just in vaguely defined megacities" (Ford, 1998, p. 537)

This claim by Ford has been re-visited by recent contributions, where we found more precise references to skyscrapers being the architectural setting for the location of the 'global' in developing countries' cities (Oktem, 2011; Kim, 2014). In developed countries' cities massive redevelopment projects have been accomplished by globally assembled capital that surpass local economic capacity (Fainstein, 1992; Lizieri, 2009; Lizieri and Pain, 2014). However, to date no explicit formal econometric test of these hypotheses has been undertaken.

In the Latin American case, we are not aware of any research connecting global flows of capital with these particular architectural settings, although we can surmise that concentrations of high buildings will be coincident with blue zones. These are areas where regulatory enforcement and government spending produce built environments comparable to first world standards, while vast extensions of the metropolis are neglected favelas, and other types of impoverished neighbourhoods (Fox, 2007).

We would like to summarize all these ideas in relation to our own research by stating that when cities have a stronger global connectivity, both local and external developers can attract global resources enabling and encouraging the development of taller buildings. In this way, the economic size of the city alone will not determine extreme building heights, as these will not be constrained by local scarcity of financial and/or technical resources for development. Traditional microeconomic explanations will be insufficient to explain building height without consideration of global connectivity and world city status. 


\section{DATA SOURCES AND EMPIRICAL STRATEGY}

\subsection{Baseline and test models}

In this section, we set up a baseline model in order to produce a test of the presented theories, combined and in isolation. The baseline model includes variables that proxy the traditional microeconomic explanation, and a time trend that represents the exogenous technology ${ }^{5}$. The model also includes regulation and building type variables.

\section{Dependent variable: Height}

This is the height in metres of the tallest building in each one of the metropolitan areas for each year in the period 2000-2012 (tallest building in a city until a new tallest building is completed). The information is principally extracted from the websites www.skyscrapercity.com, www.skyscraperpage.com, and www.emporis.com. Together these three websites have allowed us to compile information about height (in metres and floors), use (office, residential, hotel, mixed, other), location (central, peri-central, peripheral), and date of completion for 64 buildings in the 29 cities of the continent where in 2012 there was at least one building of 100 metres or taller ${ }^{6}$. The variable is introduced as a logarithm in the panel regressions, in order to interpret its relationship with economic and geographic size per cities as elasticity $^{7}$.

\section{Independent variables and the baseline model}

- Traditional theory: GDP. This is the total income of the corresponding metropolitan area 2000 - 2012 in PPP US\$ (National GDP per capita times the metro population). We have not used regional accounts where available because of a lack of international methodological and time comparability. This is an imperfect measure but these 29 cities do correspond with the more developed regions of their respective countries and, as such, they are highly

\footnotetext{
5 The time trend is used as a proxy because more direct technology variables such as Total Factor Productivity or United Nations Industrial Development Office (UNIDO) manufacturing complexity index were never significant in any estimation framework.

${ }^{6}$ The full list of cities and top buildings height are reported in the Appendix to this paper. There were 9 cases where the record holder in 2000 was less than 100 metres. We have added these buildings to the database so that we can produce complete series of tallest building replacements per city for the full period 2000-2012.

7 We need to rely on the structural height in metres, because it was impossible to construct comparable databases of more precise variables like the average height in the high buildings district per city, or the Floor-to-Area-Ratio in the plot of land with the tallest building.
} 
correlated and closer to their national averages. The variable is included as a logarithm in the empirical section and we expect it to be positively related to height.

- Traditional theory: Area. This is the amount of square kilometres destined for urban uses in each one of the metropolitan areas. In order to follow the same methodological definition in all the cities, we have used the 'measured area' procedure of the Google Earth Interface, so that we are approaching the continuous urban fabric. This is a pure cross-section variable for the year 2012. The variable is included as a logarithm in the panel estimations and we expect it to be negatively related to height, other things equal.

\section{Baseline model}

The baseline model uses these two variables extracted from the traditional microeconomic theory (GDP, Area), including a time trend, plus city and building controls that we will introduce below. This baseline model includes panel $(i t)$, cross-section $(i)$, and time-series $(t)$ variables:

$$
\text { Height }_{i t}=f\left(G D P_{i t} ; \text { Area }_{i} ; \text { Trend }_{t} ; \text { City and Building Controls } \text { Cit }\right)
$$

In order to produce tests for the contesting theories, we sequentially add their corresponding variables to the baseline model.

\section{City and Building Controls}

- City Control: UNESCO. This is a dummy for the metropolitan areas where all of their territory or their central core is a UNESCO Global Heritage Site. This declaration implies the total prohibition of new developments that change the architectural/historical cityscape. This is a pure cross-section city dummy and we expect it to be negatively associated with height in the panel estimations.

- City Control: H-H per population. This is a Herfindahl-Hirschman $(\mathrm{H}-\mathrm{H})$ index measuring the concentration of population by administrative district in the metropolitan area in $2012^{8}$. It is a pure cross-section variable, theoretically ranging from zero (no concentration) to one (total concentration in a single administrative district). We expect it to be negatively related to height in the panel estimations, because higher concentration in a single administrative spatial unit (most likely the core municipality) also concentrates regulatory enforcement powers and diminishes competition across municipal authorities.

\footnotetext{
${ }^{8}$ The H-H (Herfindahl-Hirschman) indicator is defined in our case as: $\sum_{i=1}^{n}\left(\frac{X_{i}}{X}\right)^{2}$, where $X_{i}$ is the population of each administrative spatial unit, and $X$ is the population of the entire metropolitan area.
} 
- Building Control: Central Municipality. This is a panel dummy variable with value 1 when the record building in a year is located in the core municipality of a metropolitan area. This is because the core municipality of a metropolitan area tends to have better technical and enforcement capabilities to impose height regulations when compared to its peripheral counterparts. In addition, peripheral municipalities might have more relaxed regulation schemes in order to attract scarce development resources. We expect it to be negatively associated with heights?

- Building Control: Office building. This is a panel dummy variable used when the tallest property in a metropolitan area is a building destined for office use. From the sample we have seen that this building type tends to be taller than the other types, and we expect it to be positively related to height.

\section{H-S Game Theoretic Approach: Period}

This is the period in years that the tallest building has stayed on top of its city classification, and ranges from 0 to 53 years. This number can be larger than the entire period in the database (12 years) because in some of the cities there have been no new record breaking buildings during the 2000-2012 period. This is a panel variable and is a proxy for pre-emption since, when a building stays on top of its city classification for a long period, its pre-emption of competitors must have been highly effective. We expect this variable to be positively associated with height.

We should be aware that the more recent record breaker buildings have not had enough time to manifest their excess height as pre-emption when compared with older record holders - we have a right censored data set. Because of this problem we also use a truncated regression as a robustness check. In the empirical section below, we present in more detail the problem, the technique, and the reasons why truncated regression might solve it. We also tried a standardized version of this variable, in order to correct for this potential problem; the results obtained with the standardized period are almost exactly equal to the ones reported in the paper, and consequently, are not reported in the empirical section ${ }^{10}$.

\footnotetext{
9 Most of the record-breakers are located in the central municipalities of their corresponding metropolitan areas, because of their economic potential or global character. As we already include those variables in the regression, the central municipality dummy proxies a pure location effect due to regulation.

${ }^{10}$ Results are available from the authors on request.
} 
The H-S game focuses on excess height by assuming a pre-determined city structure with differential rents and heights defined by traditional theory fundamentals. The testing of the game theory will be carried out by adding Period to the baseline model:

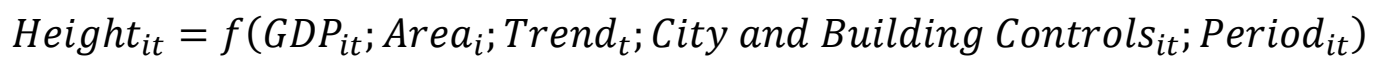

\section{Business cycle: cycle}

We estimated a Hodrick-Prescott yearly polynomial decomposition of trend and cycle for each of the ten countries' GDP per capita in current PPP US\$. We do not use constant PPP US\$ to avoid collinearity with the total GDP used in the baseline model, and also because the variable in current prices should have a clearer association with real estate cycles (Shiller, 2012).

The corresponding booms and busts were calculated as proportions in reference to their corresponding trend, and this is the panel variable used in the empirical section. The completion of record breaking buildings should occur in the economic bust and we thus expect the variable to be negatively associated with height ${ }^{11}$. As in the H-S game case, the cycle analysis deals with excess height above that predicted by the baseline model:

$$
\text { Height }_{i t}=f\left(G D P_{i t} ; \text { Area }_{i} ; \text { Trend }_{t} ; \text { City and Building Controls } i t ; \text { Cycle }_{i t}\right)
$$

\section{Global Cities: GaWC}

This is the standardized relative classification of the 29 Latin American cities as extracted from the GaWC website $^{12}$. The indicator was built by using the 2000, 2004, 2008, 2010, and 2012 rankings, and producing a relative ranking of the Latin American cities included.

This relative ranking takes the top Latin city in the ranking as the base of the index, and then divides each city's category by that base. As an example, in 2012 the top Latin American cities were Sao Paulo and Mexico City, both considered 'Alpha', while the lowest category was 'Sufficiency', located ten categories below. Buenos Aires and Santiago considered 'Alpha Minus' in 2012 have a value of 9/10 $=0.9$; Cali (Colombia) with 'Sufficiency' has $1 / 10=0.1$; cities not

11 Or at least, we expect it to be systematically associated. A measure of its strength as a predictor of the heights

12 Global and World Cities Research Centre - University of Loughborough. We are conscious of some criticisms to this classification system, although we have not found an alternative source with a panel structure and a comparable calculation structure. In addition, the GaWC model explicitly identifies the connectivity of cities in the world economic system, which is our hypothesized predictor of heights. 
classified by GaWC are scored at zero. This is a panel variable, and it is expected to be positively correlated with height:

$$
\text { Height }_{i t}=f\left(G D P_{i t} ; \text { Area }_{i} ; \text { Trend }_{t} ; \text { City and Building Controls } i t ; \text { GaWC }_{i t}\right)
$$

There is the possibility that order of causation goes from building height to the global city index, as a means of advertising. We will investigate this possibility by using instrumental variables in the empirical analyses below.

Other potential variables and controls. Other panel, cross-section and time-series were intended to be used as controls in the panel, or to be used as alternative proxies of the theories studied. However, their poor performance in terms of individual significance and model goodness of fit ruled them out in most of the exercises, including those where instrumental variables were used as described below. Variables excluded are alternative approaches to cycle: interest rate, unemployment, and currency exchange rate; building types: hotel, residential, mixed; building location: central, peri-central or peripheral; city type: national capital, and touristic; natural conditions per city: temperature, coastal location, seismic; and other country development characteristics: Gini Index of income concentration, total factor productivity, services proportion in GDP, UNIDO technological complexity index, and percentage of the labour force with higher education qualifications.

\section{Instrumental variables (IV)}

In the empirical section below, we show that there were no empirical specifications where there was correlation of any of the variables with their corresponding pooled OLS error terms. However, endogeneity is expected between some of the variables, particularly between Area, GDP, Population H-H, and GaWC. In order to avoid these problems, we use instruments that are correlated with each one of these but not with the error terms. The corresponding instruments are:

- Manufacturing: Percentage share of manufacturing in total GDP per country. The information is extracted from the Economic Council for Latin America (ECLAC) website. It is included when using GDP in the regressions.

- Manufacturing Exports: Percentage share of manufacturing in total exports per country. Extracted from the ECLAC website. It is included when using GDP in the regressions. 
- Population Density: This variable is the total population over the urban area in terms of inhabitants per square kilometre. The variable is included as a logarithm when using Area in the regressions.

- Legal area: total area of the municipalities that comprise the metropolitan area. This variable is measured in square kilometres and included as a logarithm when using Population $\mathrm{H}-\mathrm{H}$ in the regressions.

- Period on Top: accumulative years a building has remained on top of its city classification. It is included when Period is used in the regressions, and it is different from that variable because it grows in time until the building is replaced on top of the city classification.

- Growth 5 Years: average yearly per capita growth per country in the last five years. Included in the regressions that use Cycle.

- City Brand Index: as determined from surveys in the regional business community by the magazine America Economia in its Latin Cities Ranking 2012. It is included in the regressions when GaWC is used.

When using IV estimation, all the exogenous variables are also included as instruments because none of them was correlated with the error. The general quality of the IV estimation will be checked using the Sargan test. A summary of the information in the database is reported in Table 1 , and descriptive statistics are in Table 2.

\subsection{Comparison regression models}

In addition to the baseline and test models, we include a set of alternative regressions. The first one of these takes into account that very tall buildings are lengthy projects that should be determined by time-lagged independent variables, not by their contemporary realizations. The variables Period and Cycle already take into account this time-dependent structure in the proposed models, but we also perform a specification where the traditional theory and global cities variables are lagged $n$ periods. We expect that the results of this regression will replicate the results of the models described by equations 1 to 4 :

$$
\text { Height }_{i t}=f\left(G D P_{i t-n} ; \text { Area }_{i} ; \text { Trend }_{t} ; \text { City and Building Controls } \text { Cit }_{i} ; \text { GaWC }_{i t-n}\right)
$$

A second alternative regression will use a different dependent variable: the number of high rise buildings (more than 100 metres tall) in each city-year: Highrises. The Highrises variable captures 
predominance and change in high building development as a function of the same independent variables presented in section 3.1. This regression will be slightly different to the models represented in equations 1 to 4, because, by definition, it cannot have building controls, only city controls:

$$
\text { Highrises }_{i t}=f\left(\text { GDP }_{i t} ; \text { Area }_{i} ; \text { Trend }_{t} ; \text { City Controls }_{i} ; \text { GaWC }_{i t}\right)
$$

In the third alternative regression, the dependent variable will be the height of the top building when compared to the average of all the other highrise in the city per year (Height $_{\text {it }}$ /Average Highrises ${ }_{i t}$ ). This variable will be named Excess Height, and we expect it to be determined by the same variables as height in equations 1 to 4 :

Excess Height $_{i t}=f\left(G D P_{i t} ;\right.$ Area $_{i} ;$ Trend $_{t} ;$ City and Building Controls $i t ;$ GaWC $\left._{i t}\right)$ 
Table 1: Summary of information in the database

\begin{tabular}{|c|c|c|c|}
\hline Variable & Source & Units & Type \\
\hline Height & $\begin{array}{l}\frac{\text { www.skyscraperpage.com }}{\text { www.skyscrapercity.com }} \\
\text { www.emporis.com } \\
\text { adapted to building-city observations }\end{array}$ & Meters & Panel \\
\hline GDP & $\begin{array}{l}\text { Heston et al. (2012), PWT } 7.1 \\
\text { Feenstra et al. (2013), PWT } 8.0 \\
\text { www.eclac.org }\end{array}$ & $\begin{array}{l}\text { Billions of } \\
\text { constant } 2005 \\
\text { PPP dollars }\end{array}$ & Panel \\
\hline Area & $\begin{array}{l}\text { www.googleearth.com area measure } \\
\text { interface }\end{array}$ & $\begin{array}{l}\text { Thousands of } \\
\mathrm{Km}^{2}\end{array}$ & $\begin{array}{l}\text { Cross- } \\
\text { section }\end{array}$ \\
\hline UNESCO & www.unesco.org & Dummy & $\begin{array}{l}\text { Cross- } \\
\text { section }\end{array}$ \\
\hline $\begin{array}{l}\text { Central } \\
\text { Municipality }\end{array}$ & $\begin{array}{l}\text { The building is located in the central } \\
\text { municipality of the metropolitan area }\end{array}$ & Dummy & Panel \\
\hline $\begin{array}{l}\text { Population } \mathrm{H}- \\
\mathrm{H}\end{array}$ & $\begin{array}{l}\text { Own calculation using countries' statistics } \\
\text { and geographical agencies }\end{array}$ & Index $\left[\frac{1}{n}: 1\right]$ & $\begin{array}{l}\text { Cross- } \\
\text { section }\end{array}$ \\
\hline Office & $\begin{array}{l}\frac{\text { www.skyscraperpage.com }}{\text { www.skyscrapercity.com }} \\
\text { www.emporis.com } \\
\text { adapted to building-city observations }\end{array}$ & Dummy & Panel \\
\hline Period & $\begin{array}{l}\text { www.skyscraperpage.com } \\
\text { www.skyscrapercity.com } \\
\text { www.emporis.com } \\
\text { adapted to building-city observations }\end{array}$ & Years & Panel \\
\hline Cycle & $\begin{array}{l}\text { H-P decomposition of current PPP US\$ } \\
\text { GDP per capita }\end{array}$ & Percentage & $\begin{array}{l}\text { Time-series } \\
\text { per } \\
\text { countries }\end{array}$ \\
\hline GaWC & $\begin{array}{l}\text { Standardized } 0-1 \text { measure extracted from } \\
\text { rankings at www.lboro.ac.uk/gawc }\end{array}$ & Index $0-1$ & Panel \\
\hline Manufacturing & CECLAC www.cepal.org & Percentage & Panel \\
\hline $\begin{array}{l}\text { Manufacturing } \\
\text { Exports }\end{array}$ & CECLAC www.cepal.org & Percentage & Panel \\
\hline Density & $\begin{array}{l}\text { [Population / Area] using countries' } \\
\text { statistics and geographical agencies. }\end{array}$ & $\begin{array}{l}\text { Population per } \\
\text { hectare }\end{array}$ & Panel \\
\hline Legal Area & $\begin{array}{l}\text { Countries' statistics and geographical } \\
\text { agencies }\end{array}$ & $\begin{array}{l}\text { Thousands of } \\
\mathrm{Km}^{2}\end{array}$ & $\begin{array}{l}\text { Cross- } \\
\text { section }\end{array}$ \\
\hline Period on Top & $\begin{array}{l}\text { www.skyscraperpage.com } \\
\frac{\text { www.skyscrapercity.com }}{\text { www.emporis.com }} \\
\text { adapted to building-city observations }\end{array}$ & Years & Panel \\
\hline Growth 5 Years & $\begin{array}{l}\text { Average yearly growth of the PPP US\$ } \\
\text { GDP per capita in the immediate } 5 \text { years }\end{array}$ & Rate & Panel \\
\hline $\begin{array}{l}\text { City Brand } \\
\text { Index }\end{array}$ & $\begin{array}{l}\text { Determined by America Economia } \\
\text { Magazine in its Latin Cities Ranking } \\
2012 \text { www.americaeconomia.com }\end{array}$ & Index $0-1$ & $\begin{array}{l}\text { Cross- } \\
\text { section }\end{array}$ \\
\hline
\end{tabular}

* Population is extracted from each country's corresponding bureau of statistics 
Table 2: Descriptive statistics of the variables (2000-2012)

\begin{tabular}{|l|r|r|r|r|}
\hline \multicolumn{1}{|c|}{ Variable } & Mean & Std. Desv. & \multicolumn{1}{c|}{ Max } & min \\
\hline Height & 141.58 & 42.60 & 284.00 & 65.00 \\
\hline GDP & 38.60 & 55.10 & 263.00 & 2.13 \\
\hline Area & 0.51 & 0.54 & 2.28 & 0.05 \\
\hline UNESCO & 0.21 & 0.41 & 1.00 & 0.00 \\
\hline Central Municipality & 0.96 & 0.17 & 1.00 & 0.00 \\
\hline Population H-H & 0.52 & 0.30 & 1.00 & 0.04 \\
\hline Office & 0.46 & 0.50 & 1.00 & 0.00 \\
\hline Period & 19.79 & 14.45 & 53.00 & 0.00 \\
\hline Cycle & -0.01 & 0.04 & 0.12 & -0.20 \\
\hline GaWC & 0.28 & 0.34 & 1.00 & 0.00 \\
\hline Manufacturing & 17.91 & 3.81 & 30.95 & 5.27 \\
\hline Manufacturing Exports & 42.57 & 23.72 & 85.24 & 2.33 \\
\hline Density & 88.96 & 53.47 & 230.48 & 7.72 \\
\hline Legal Area & 4.68 & 5.18 & 23.91 & 0.08 \\
\hline Period on Top & 14.59 & 11.83 & 53.00 & 0.00 \\
\hline Growth 5 Years & 0.02 & 0.02 & 0.11 & -0.07 \\
\hline Brand City Index & 0.60 & 0.21 & 0.96 & 0.32 \\
\hline
\end{tabular}

\section{REGRESSION RESULTS}

In this section, we present regression results using four different pooled estimation techniques: principally, an Instrumental Variables (IV) approach that allows us to deal with possible endogeneity problems; However, in order to understand the order of incorporation of variables in the analysis, we begin with Ordinary Least Squares (OLS); correlation drives us to confirm these results using FML; Truncated Regression (Trunc.) is also used because of the particular distribution over time of the variable Period. Finally, the preferred IV results are presented.

We use a pooled structure because it is a flexible and feasible estimation in cases like ours, where we combine panel variables (Height, GDP, GaWC), pure cross-section variables (Area, Unesco, Population $\mathrm{H}-\mathrm{H}$ ), and pure time series variables (Cycle). Because of this specification, we cannot use a cross-section or period fixed effects model, and consequently there are no comparison outputs for random effects estimations ${ }^{13}$.

\footnotetext{
${ }^{13}$ We have however run the same specifications when replacing Area with Density (its semi-panel derived variable), and when not excluding Unesco and Population $\mathrm{H}-\mathrm{H}$ in these regressions. The signs and significance of the estimated parameters do not change. We use instrumental variables in order to be reasonably sure that there are not indirect causation effects between the explanatory variables.
} 


\subsection{Pooled results}

In Table 3, we report six different specifications of the proposed tests when using Pooled OLS. Pool1 and Pool2 use traditional theory variables and controls, while the game theory variable is included in Pool3 and Pool3Tr., the truncated estimation. The Pool4 represents the business cycle model, and Pool5 includes the global cities variable. In Pool 6 we use all the variables from the competing theories.

In Table 3 we see an increase of both $\mathrm{R}^{2}$ and adjusted $\mathrm{R}^{2}$, and a decrease in the standard error with the inclusion of more variables in each model. All the models satisfy normality tests according to the Kolmogorov-Smirnov statistic. Unfortunately, and regardless the use of a time trend, all the models have strong temporal correlation according to the one-lag Q-Statistic. However, and as we are working in a panel environment, we have also shown the p-value of the non-heteroskedastic random walk test or Variance Ratio Test. We can see that the residuals of all the models behave as a Martingale and, in spite of temporal correlation, are not heteroskedastic, and not predicted by their past values.

The results in Table 3 support the idea that traditional theory variables are good predictors of top building height per city, since the GDP effect is always positive and Area is always negative. The controls typically exhibit their expected signs and are significant. Pooled6 was the only specification where GDP was non-significant.

We used two different techniques to analyse the effect of the H-S game theory variable Period. In Pool3 we use OLS while in Pool3Tr. the estimation is time-truncated. This is because the most recent record breakers have had insufficient time to manifest any pre-emption effects that their height could produce, causing a biased estimation for the variable Period. 
Table 3: OLS top height determinants

\begin{tabular}{|c|c|c|c|c|c|c|c|c|c|c|c|}
\hline & & \multicolumn{8}{|c|}{ Dependent variable: $\log$ (height) } & \multirow{2}{*}{$\begin{array}{l}\text { Dep. Var: } \\
\text { Highrises }\end{array}$} & \multirow{2}{*}{$\begin{array}{l}\text { Dep. Var: } \\
\text { Exc. Height }\end{array}$} \\
\hline & & Pool 1 & Pool 2 & Pool 3 & Pool 3 Tr. & Pool 4 & Pool 5 & Pool 6 & 2 years lag & & \\
\hline & & -0.050 & 0.203 & 0.101 & 0.060 & 0.074 & $3.272 * * *$ & $3.052^{* * *}$ & $1.359^{* * *}$ & 15.599 & $1.840^{* * *}$ \\
\hline & & 0.346 & 0.362 & 0.370 & 0.357 & 0.365 & 0.490 & 0.506 & 0.507 & 45.757 & 0.371 \\
\hline \multirow{4}{*}{$\begin{array}{c}\text { Traditional } \\
\text { Theory }\end{array}$} & \multirow{2}{*}{ GDP } & $0.210^{* * *}$ & $0.218^{* * *}$ & $0.226^{* * *}$ & $0.228^{* * *}$ & $0.219^{* * *}$ & $0.077^{* * *}$ & $0.085^{* * *}$ & $0.175^{* * *}$ & -2.806 & -0.028 \\
\hline & & 0.018 & 0.018 & 0.019 & 0.019 & 0.018 & 0.024 & 0.025 & 0.023 & 2.153 & 0.018 \\
\hline & \multirow{2}{*}{ Area } & $-0.087 * * *$ & $-0.122 * * *$ & $-0.125 * * *$ & $\overline{-0.124^{* * *}}$ & $-0 . \overline{122} * * *$ & $-0.111 * * *$ & $-0 . \overline{112} * * *$ & $-0.124 * * *$ & $1 . \overline{379}$ & $-\overline{-0.057} * * *$ \\
\hline & & 0.020 & 0.020 & 0.020 & 0.020 & 0.020 & 0.019 & 0.019 & 0.020 & 1.700 & 0.014 \\
\hline \multirow{10}{*}{$\begin{array}{l}\text { City and } \\
\text { Building } \\
\text { Controls }\end{array}$} & \multirow{2}{*}{ Trend } & $0.165^{* * *}$ & $0.169 * * *$ & $0.143^{* *}$ & $0.140^{* *}$ & $0.206^{* * *}$ & $0.202^{* * *}$ & $0.212^{* * *}$ & $0.119 *$ & $15.933^{* * *}$ & $0.131^{* * *}$ \\
\hline & & 0.059 & 0.056 & 0.059 & 0.058 & 0.059 & 0.052 & 0.057 & 0.062 & 49.559 & 0.042 \\
\hline & \multirow{2}{*}{ UNESCO } & & $-\overline{0.128} * * *$ & $\overline{-0.145 * * *}$ & $-0.147 * * *$ & $-0.128^{* * *}$ & $-0.073 * * *$ & $-0.083^{* * *}$ & $-0.122 * * *$ & 2.292 & 0.012 \\
\hline & & & 0.030 & 0.032 & 0.031 & 0.030 & 0.028 & 0.030 & 0.032 & 2.552 & 0.022 \\
\hline & \multirow{2}{*}{$\begin{array}{l}\text { HH per } \\
\text { population }\end{array}$} & & $-\overline{0.057}$ & $\overline{-0.028}$ & $-\overline{0.012}$ & $\overline{-0.055}$ & $-0.098 * *$ & $\overline{-0.080}$ & -0.045 & $\overline{-4.583}$ & $-0.087 * *$ \\
\hline & & & 0.053 & 0.057 & 0.045 & 0.052 & 0.048 & 0.052 & 0.055 & 4.302 & 0.038 \\
\hline & \multirow{3}{*}{$\begin{array}{c}\text { Central } \\
\text { Municipality }\end{array}$} & & $-0.221 * * *$ & $-\overline{-0.214} * \overline{* * *}$ & $\overline{-0.220^{* * *}}$ & $-0 . \overline{228} * * *$ & $-0.225 * * *$ & $-0 . \overline{226} * * *$ & $-0.217 * * *$ & & $-0.17 * * *$ \\
\hline & & & 0.062 & 0.062 & 0.060 & 0.062 & 0.057 & 0.057 & 0.061 & & 0.042 \\
\hline & & & $0 . \overline{050} * *$ & $0.058^{* *}$ & $0.059 * *$ & $\overline{0.050^{* *}}$ & 0.030 & $\overline{0.035}$ & $0.049^{*}$ & & 0.008 \\
\hline & Office & & 0.025 & 0.026 & 0.025 & 0.025 & 0.023 & 0.024 & 0.025 & & 0.017 \\
\hline \multirow{2}{*}{$\begin{array}{l}\text { Game } \\
\text { Theory }\end{array}$} & \multirow{2}{*}{ Period?100 } & & & -0.135 & -0.148 & & & -0.077 & -0.001 & & -0.028 \\
\hline & & & & 0.100 & 0.095 & & & 0.001 & 0.001 & & 0.001 \\
\hline \multirow{2}{*}{$\begin{array}{c}\text { Busines } \\
\text { Cycle }\end{array}$} & \multirow{2}{*}{ Cycle } & & & & & $-0.647 * *$ & & -0.445 & -0.156 & 16.478 & 0.169 \\
\hline & & & & & & 0.301 & & 0.278 & 0.300 & 2.551 & 0.204 \\
\hline Global & \multirow{2}{*}{ GaWc } & & & & & & $0.505 * * *$ & $0.493^{* * *}$ & $0.238^{* * *}$ & $57.031 * * *$ & $0.706^{* * *}$ \\
\hline \multirow[t]{4}{*}{ Cities } & & & & & & & 0.059 & 0.060 & 0.057 & 5.451 & 0.044 \\
\hline & Adjusted $R^{2}$ & 0.376 & 0.431 & 0.432 & & 0.437 & 0.523 & 0.526 & 0.464 & 0.489 & 0.637 \\
\hline & $R^{2}$ & 0.381 & 0.442 & 0.444 & & 0.449 & 0.533 & 0.537 & 0.478 & 0.499 & 0.647 \\
\hline & Std Error & 0.237 & 0.227 & 0.226 & 0.287 & 0.226 & 0.207 & 0.207 & 0.220 & 19.067 & 0.152 \\
\hline \multicolumn{2}{|c|}{ Kolmogorov-Smirnov } & 0.000 & 0.488 & 0.550 & 0.561 & 0.554 & 0.300 & 0.402 & 0.000 & 0.000 & 0.000 \\
\hline & Q-Stat (1 lag) & 0.000 & 0.000 & 0.000 & 0.000 & 0.000 & 0.000 & 0.000 & 0.000 & 0.000 & 0.000 \\
\hline \multicolumn{2}{|c|}{ Var. Ratio Test ( $p$-value) } & 0.866 & 0.850 & 0.874 & 0.874 & 0.897 & 0.109 & 0.997 & 0.988 & 0.999 & 0.993 \\
\hline & Scale & & & & 0.224 & & & & & & \\
\hline \multicolumn{2}{|c|}{ Redundant vars. ( $p$-value) } & & & & 0.000 & & & & & & \\
\hline \multicolumn{2}{|c|}{ Corr. to error $(<10 \%)$} & none & none & none & none & none & none & none & & & \\
\hline
\end{tabular}

Period: 2000 - 2012; Cities: 29; Observations: 377

*** Significant at $1 \%$; ** Significant at $5 \%$; *Significant at $10 \%$

Standard errors in italics under the corresponding estimated parameter

Kolmogorov-Smirnov is the p-value of the test: $\mathrm{H}_{0}$ : the residuals are normal $\left(0, \sigma^{2}\right)$

$\mathrm{Q}$-Stat is the $\mathrm{p}$-value of the test $\mathrm{H}_{0}$ : the residuals do not have one lag temporal correlation

Variance Ratio Test. $\mathrm{H}_{0}$ : residuals are a martingale

Highrises: the dependent variable is the number of buildings with 100 metres or more.

Exc. Height: the dependent variable is (height of tallest building/average height of all the highrises).

2 years lag: the variables GDP, Area and GaWC are two-years lags of the corresponding contemporaneous variables. 
The residuals in our estimations can have a high degree of correlation because the tallest buildings height is an extremely time-dependent variable, and each year that a building stays on top of the classification its height is equal to (exactly predicted by) its height in the immediately preceding year. We will try to solve this problem by adding a time trend in all of the estimations, but, as we will see, this solution is insufficient and FML estimation will be used as a robustness check of the OLS results.

The truncated estimation has been developed in the context of so-called survival models, because the most recently born individuals sampled from wild populations (of animals) might not yet have developed the adult characteristics under scrutiny. In the case of a pooled model and, following Greene (2004), the observed realizations of the dependent variable $y_{i t}^{*}=\alpha+$ $x_{i t}^{\prime} \beta+\varphi \epsilon_{i t}$, belong to the full set of non-truncated observations $y_{i t}=y_{i t}^{*}$ if $y_{i t}^{*}<\bar{c}_{i T}$, their values in the last available period. The log-likelihood will now include not only all the pooled residuals, but the difference between them and the residuals of all the cross-sections in the last period. It will also include the parameter $\varphi$ (Scale) weighting all the residuals and the resulting standard error of the regression ${ }^{14}$.

We can see in Table 3 that Period was non-significant in all specifications, whether or not truncated estimation was used. We are unable to demonstrate that the game theoretic approach provides a model of tallest building height, at least in this estimation context. We can also see in Table 3 that, in the truncated regression none of the parameters signs and significance levels changed; this means that the non-truncated estimations can be used in our remaining analyses.

The business cycle variable was negative and significant in Pool4, but it was non-significant in Pool6. Thus the results are inconclusive as to whether the business cycle explanation is valuable as a model for determining top building height in cities. Further analyses are necessary before conclusions can be drawn.

Finally, the global cities variable performed well and with the expected sign in all the models where it was included. The satisfactory performance of this variable along with the findings set out in Table 3 will be checked by performing the same set of regressions using FML in Table 4.

\footnotetext{
${ }^{14}$ Greene (2004) detects that truncation will produce biases in the estimation of the $\beta$ vector and the fixed effects; however, in our simple pooled estimation we have only one of these two sources of bias, as we do not have fixed effects.
} 
We use FML because, regardless of the normality and random walk character of the residuals from the various models, the existence of temporal correlation might bias the standard errors, and the corresponding confidence intervals ${ }^{15}$.

It can be appreciated that in Table 4, with the number of variables in the models, both the LogLikelihood increases and the Akaike criterion decreases. However, the Akaike for model FML5 is smaller than for model FML6, evidence of a certain degree of redundancy. All the models are still strongly normal according to Kolmogorov-Smirnov, they are also still temporally correlated according to the Q-Stat, but their errors behave as a Martingale from the Variance Ratio Test.

The results in Table 4 confirm those found in Table 3 for all models, except Pool6. This means that the possible standard errors estimation bias caused by the temporal correlation does not lead us to wrong conclusions when using the p-values of the OLS, except when all the theories are combined in Pool6. The main difference between Pool6 and FML6 is that the first model rejects GDP, but the second rejects HH per Population. As we already know that GDP, Area, HH per Population, and GaWC might be endogenous, we perform the same set of estimations of Tables 3 and 4 using IV in the next section.

As a final remark in this section, we note that the time trend was always positive and significant, UNESCO was always negative and significant, and Central Municipality was also always negative and significant. These controls behave well regardless of estimation technique and produce their expected signs. HH per population is negative but non-significant in most specifications, and the office building performed well in all the specifications where the GaWC index was not included. Since GaWC's measure of connectivity focuses on office-based international service firms, there is likely to be some connection between the two indicators.

15 Quantile regressions (results available from the authors) allowed us to detect that our estimates are also maxconsistent in terms of signs and significance of the parameters, although there is a significant change of the parameters from the median to the $5^{\text {th }}$ quintile. 
Table 4: FML Top height determinants

\begin{tabular}{|c|c|c|c|c|c|c|c|c|c|c|}
\hline & & \multicolumn{7}{|c|}{ Dependent variable: $\log$ (height) } & \multirow{2}{*}{$\begin{array}{l}\text { Dep. Var: } \\
\text { Highrises }\end{array}$} & \multirow{2}{*}{$\begin{array}{l}\text { Dep. Var: } \\
\text { Exc. Height }\end{array}$} \\
\hline & & FML 1 & FML 2 & FML 3 & FML 4 & FML 5 & FML 6 & 2 years lag & & \\
\hline & \multirow{2}{*}{ c } & -0.050 & 0.203 & 0.101 & 0.074 & $3.272 * * *$ & $3.052 * * *$ & $1.359^{* * *}$ & 15.769 & $1.840^{* * *}$ \\
\hline & & 0.375 & 0.474 & 0.490 & 0.477 & 0.514 & 0.543 & 0.508 & 79.187 & 0.440 \\
\hline \multirow{4}{*}{$\begin{array}{c}\text { Traditional } \\
\text { Theory }\end{array}$} & \multirow{2}{*}{ GDP } & $0.210^{* * *}$ & $0.218^{* * *}$ & $0.226 * * *$ & $0.219^{* * *}$ & $0.077^{* * *}$ & $0.085^{* * *}$ & $0.175^{* * *}$ & -2.814 & -0.028 \\
\hline & & 0.019 & 0.021 & 0.023 & 0.021 & 0.023 & 0.026 & 0.023 & 4.126 & 0.024 \\
\hline & \multirow{2}{*}{ Area } & $\overline{-0.087} \overline{* * *}$ & $\overline{-0.122} * * *$ & $-0.125 * * *$ & $\overline{-0.122 * * *}$ & $-0 . \overline{111} * \bar{*}$ & $-\overline{-0.112 * * *}$ & $-0 . \overline{124} * \bar{*}$ & $\overline{1.381}$ & $-0 . \overline{057} * * *$ \\
\hline & & 0.020 & 0.021 & 0.022 & 0.021 & 0.017 & 0.018 & 0.020 & 2.979 & 0.019 \\
\hline \multirow{10}{*}{$\begin{array}{l}\text { City and } \\
\text { Building } \\
\text { Controls }\end{array}$} & \multirow{2}{*}{ Trend } & $0.165^{* * *}$ & $0.169 * * *$ & $0.143 * *$ & $0.206^{* * *}$ & $0.202 * * *$ & $0.212 * * *$ & $0.119 *$ & $15.936 * *$ & 0.131 *** \\
\hline & & 0.060 & 0.057 & 0.068 & 0.058 & 0.055 & 0.063 & 0.067 & 6.470 & 0.047 \\
\hline & \multirow{2}{*}{ UNESCO } & & $-\overline{0.128} \overline{* * *}$ & $\overline{-0.145 * * *}$ & $-0 . \overline{128} * \overline{* *}$ & $-0.073 * * *$ & $\overline{-0.083} * \overline{* *}$ & $\overline{-0.122} 2^{* * *}$ & $2 . \overline{294}$ & $\overline{0.012}$ \\
\hline & & & 0.029 & 0.034 & 0.029 & 0.026 & 0.031 & 0.032 & 3.340 & 0.024 \\
\hline & \multirow{2}{*}{$\begin{array}{c}\overline{\mathrm{H}} \mathrm{H} \overline{\text { per }} \\
\text { population }\end{array}$} & & $\overline{-0.057}$ & $\overline{-0.028}$ & $-\overline{0.055}$ & $\overline{-0.098 *}$ & -0.080 & $\overline{-0.045}$ & $-\overline{4.588}$ & $-0.0 \overline{87} * *$ \\
\hline & & & 0.057 & 0.065 & 0.057 & 0.054 & 0.063 & 0.063 & 4.693 & 0.042 \\
\hline & \multirow{2}{*}{$\begin{array}{c}\text { Central } \\
\text { Municipality }\end{array}$} & & $\overline{-0.221} * *$ & $-\overline{0.214} \overline{* *}$ & $\overline{-0.228 * * *}$ & $-0 . \overline{225} * * *$ & $-\overline{-0.226 * * *}$ & $-0 . \overline{217} * \overline{* *}$ & & $-0 . \overline{168} * * *$ \\
\hline & & & 0.090 & 0.089 & 0.088 & 0.073 & 0.072 & 0.084 & & 0.051 \\
\hline & \multirow{2}{*}{ Office } & & $0 . \overline{050}$ * & $\overline{0.058 * *}$ & $0 . \overline{050} *$ & $\overline{0.030}$ & 0.035 & $\overline{0.049} *$ & & $0 . \overline{0082}$ \\
\hline & & & 0.026 & 0.027 & 0.026 & 0.027 & 0.028 & 0.027 & & 0.024 \\
\hline \multirow{2}{*}{$\begin{array}{l}\text { Game } \\
\text { Theory }\end{array}$} & \multirow{2}{*}{ Period $\cdot 100$} & & & -0.135 & & & -0.077 & -0.001 & & -0.028 \\
\hline & & & & 0.141 & & & 0.127 & 0.001 & & 0.001 \\
\hline Busines & \multirow{2}{*}{ Cycle } & & & & $-0.647 * *$ & & -0.445 & -0.156 & 16.487 & 0.168 \\
\hline Cycle & & & & & 0.292 & & 0.322 & 0.317 & 33.138 & 0.190 \\
\hline Global & \multirow{2}{*}{ GaWC } & & & & & $0.505^{* * *}$ & $0.493^{* * *}$ & $0.238^{* * *}$ & $57.049 * * *$ & $0.706^{* * *}$ \\
\hline Cities & & \multirow[b]{2}{*}{9.423} & \multirow[b]{2}{*}{28.773} & \multirow[b]{2}{*}{29.698} & & 0.056 & 0.056 & 0.059 & 10.071 & 0.045 \\
\hline \multicolumn{2}{|c|}{ Log-Likelihood } & & & & 31.123 & 62.509 & 64.194 & 41.414 & $-1,642.277$ & -1602.142 \\
\hline & Akaike Crit. & -0.029 & -0.110 & -0.110 & -0.117 & -0.284 & -0.282 & -0.161 & 8.755 & 8.558 \\
\hline & Std Error & 0.237 & 0.227 & 0.226 & 0.226 & 0.207 & 0.207 & 0.220 & 19.067 & 0.152 \\
\hline Kolmog & orov-Smirnov & 0.403 & 0.488 & 0.550 & 0.554 & 0.300 & 0.383 & 0.000 & 0.000 & 0.000 \\
\hline & Q-Stat (1 lag) & 0.000 & 0.000 & 0.000 & 0.000 & 0.000 & 0.000 & 0.000 & 0.000 & 0.000 \\
\hline Var. Ratio & Test (p-value) & 0.866 & 0.850 & 0.874 & 0.897 & 0.109 & 0.997 & 0.988 & 0.999 & 0.999 \\
\hline
\end{tabular}

Period: $2000-2012$; Cities: 29; Observations: 377

*** Significant at $1 \%$;* Significant at $5 \%$; * Significant at $10 \%$

Standard errors in italics and immediately under the corresponding parameter

Kolmogorov-Smirnov is the p-value of the test: $\mathrm{H}_{0}$ : the residuals are normal $\left(0, \sigma^{2}\right)$

Q-Stat is the p-value of the test $\mathrm{H}_{0}$ : the residuals do not have one lag temporal correlation

Variance Ratio Test. $\mathrm{H}_{0}$ : residuals are a martingale

Highrises: the dependent variable is the number of buildings with 100 metres or more.

Exc. Height: the dependent variable is (height of tallest building/average height of all the highrises).

2 years lag: the variables GDP, Area and GaWC are two-years lags of the corresponding contemporaneous variables. 


\subsection{Instrumental Variables}

In Table 5 we present the IV results. As noted in the regression context section, we have not found any variables correlated with the corresponding residuals. However, potential endogeneity between some of the variables might still justify use of an IV approach. In particular, GDP and Area are expected to be endogenous because the largest urban economies will typically occupy the largest territories; this expectation gets confirmed by a correlation of 0.84 . GDP will be instrumented by Manufacturing as a proportion of GDP, a measure of internal market size in national economies, and also by Manufacturing Exports, a measure of economic complexity.

We over-identify GDP with two instruments because it also highly correlated with GaWC (0.79). This was an expected association because the larger urban economies are also the most sophisticated and connected with international flows. GaWC in turn will be instrumented by the America Economia City Brand Index 2012. We will control the quality of these over-identified estimations by reporting the p-value of the corresponding Sargan tests in Table 3.

The other variables and instruments are as follows: Area will be instrumented by population density, a related but time-moving variable; $\mathrm{HH}$ per population, which is correlated with area (0.604), will be instrumented by legal area; Period is not strongly correlated with any variable, but as the test variables GaWC, GDP, and Area are being instrumented we have decided to keep symmetry and it is instrumented by Period on Top; the same applies to Cycle, which will be instrumented by the variable Growth 5 Years.

As a matter of structure, all the non-endogenous variables were included as instruments in the corresponding model specification. This is because they are also not correlated with the corresponding residuals (Greene, 2008).

All of the models presented in Table 5 satisfy the Kolmogorov-Smirnov normality test, except IV3 where the game theory approach is tested. All of them have temporal correlation according to the Q-Statistic, although models IV4, IV5, and IV6, are still non-heteroskedastic Martingales. These will be our preferred models. 
Table 5: IV Top height determinants

\begin{tabular}{|c|c|c|c|c|c|c|c|c|c|c|}
\hline & & \multicolumn{7}{|c|}{ Dependent variable: $\log$ (height) } & \multirow{2}{*}{$\begin{array}{l}\text { Dep. Var: } \\
\text { Highrises }\end{array}$} & \multirow{2}{*}{$\begin{array}{l}\text { Dep. Var: } \\
\text { Exc. Height }\end{array}$} \\
\hline & & IV 1 & IV 2 & IV 3 & IV 4 & IV 5 & IV 6 & 2 years lag & & \\
\hline & \multirow{2}{*}{ C } & $5.024^{* * *}$ & $4.925 * * *$ & $5.279 * * *$ & $4.911 * * *$ & $7.130 * * *$ & 7.226 *** & $9.559 * * *$ & 25.516 & $1.484^{* *}$ \\
\hline & & 1.699 & 1.124 & 1.221 & 1.136 & 0.983 & 1.024 & 1.744 & 86.422 & 0.630 \\
\hline \multirow{4}{*}{$\begin{array}{c}\text { Traditional } \\
\text { Theory }\end{array}$} & \multirow{2}{*}{ GDP } & 0.056 & $0.082 *$ & 0.048 & 0.078 * & -0.070 & $-0.082 *$ & $-0.135 *$ & -0.361 & -0.009 \\
\hline & & 0.061 & 0.042 & 0.051 & 0.042 & 0.044 & 0.047 & 0.070 & 3.799 & 0.029 \\
\hline & \multirow{2}{*}{ Area } & $\overline{-0.394} \overline{* * *}$ & $\overline{-0.373} * \bar{*}$ & $-\overline{0.352} \overline{* * *}$ & $\overline{-0.375 * * *}$ & $-0 . \overline{193} * * *$ & $-\overline{-0.187} 7^{* * *}$ & $-0 . \overline{202} * * *$ & $\overline{-4.824}$ & $-0 . \overline{070} * * *$ \\
\hline & & 0.104 & 0.061 & 0.056 & 0.062 & 0.032 & 0.029 & 0.038 & 3.278 & 0.018 \\
\hline \multirow{10}{*}{$\begin{array}{l}\text { City and } \\
\text { Building } \\
\text { Controls }\end{array}$} & \multirow{2}{*}{ Trend } & $0.283^{* *}$ & $0.277^{* * *}$ & $0.378 * * *$ & $0.313^{* * *}$ & $0.249^{* * *}$ & $0.300 * * *$ & -0.041 & $14.773^{* *}$ & $0.144^{* * *}$ \\
\hline & & $-\underline{0.131}$ & 0.099 & 0.116 & 0.108 & 0.064 & 0.079 & 0.124 & 6.125 & 0.048 \\
\hline & \multirow{2}{*}{ UNESCO } & & $-\overline{0.117} \overline{* *}$ & -0.061 & $-0 . \overline{115} * *$ & -0.009 & $0 . \overline{008}$ & $\overline{0.035}$ & $2 . \overline{503}$ & -0.006 \\
\hline & & & 0.053 & -0.063 & 0.054 & 0.037 & -0.044 & 0.061 & 3.213 & 0.027 \\
\hline & \multirow{2}{*}{$\begin{array}{c}\text { HH per } \\
\text { population }\end{array}$} & & $\overline{-1.254} \overline{4^{* * *}}$ & $-1 . \overline{274} * \overline{* *}$ & $-1.278 * * *$ & $\overline{-0.680} * \bar{*}$ & $-0 . \overline{693} * * *$ & $\overline{-0.861} * * *$ & $-4 \overline{7.630} \overline{* * *}$ & $\overline{-0.153}$ \\
\hline & & & 0.299 & 0.304 & 0.304 & -0.179 & 0.178 & 0.247 & 17.705 & 0.110 \\
\hline & \multirow{2}{*}{$\begin{array}{c}\text { Central } \\
\text { Municipality }\end{array}$} & & $\overline{0.032}$ & $-\overline{0.022}$ & 0.033 & $-0 . \overline{087}$ & $\overline{-0.102}$ & $\overline{-0.071}$ & & $-0 . \overline{146} * * *$ \\
\hline & & - & -0.132 & 0.121 & $-\underline{0.133}$ & 0.086 & 0.080 & 0.107 & & 0.049 \\
\hline & \multirow{2}{*}{ Office } & & $0 . \overline{100} * *$ & $\overline{0.078}$ & $0.100^{* *}$ & $\overline{0.003}$ & -0.003 & $-\overline{0.011}$ & & $0 . \overline{0248}$ \\
\hline & & & 0.048 & 0.049 & 0.048 & 0.030 & 0.032 & 0.044 & & 0.020 \\
\hline \multirow{2}{*}{$\begin{array}{l}\text { Game } \\
\text { Theory }\end{array}$} & \multirow{2}{*}{ Period·100 } & & & $0.005^{* *}$ & & & 0.001 & 0.001 & & -0.063 \\
\hline & & & & 0.003 & & & 0.002 & 0.002 & & 0.001 \\
\hline \multirow{2}{*}{$\begin{array}{c}\text { Busines } \\
\text { Cycle }\end{array}$} & \multirow{2}{*}{ Cycle } & & & & -0.573 & & -0.408 & -0.058 & 58.019 & -0.009 \\
\hline & & & & & 0.704 & & 0.460 & 0.639 & 41.303 & 0.283 \\
\hline \multirow{5}{*}{$\begin{array}{l}\text { Global } \\
\text { Cities }\end{array}$} & \multirow{2}{*}{ GaWC } & & & & & $0.920 * * *$ & $0.931 * * *$ & $1.269 * * *$ & $34.854^{* * *}$ & $0.563 * * *$ \\
\hline & & & & & & 0.141 & 0.140 & 0.248 & 12.330 & 0.086 \\
\hline & Adjusted $\mathrm{R}^{2}$ & -1.872 & -0.672 & -0.612 & -0.706 & 0.284 & 0.283 & -0.300 & 0.307 & 0.615 \\
\hline & $R^{2}$ & -1.850 & -0.640 & -0.647 & -0.670 & 0.299 & 0.302 & -0.266 & 0.319 & 0.625 \\
\hline & Std Error & 0.509 & 0.388 & 0.386 & 0.393 & 0.254 & 0.254 & 0.343 & 22.217 & 0.157 \\
\hline \multicolumn{2}{|c|}{ Kolmogorov-Smirnov } & 0.503 & 0.100 & 0.052 & 0.156 & 0.243 & 0.502 & 0.000 & 0.000 & 0.000 \\
\hline & Q-Stat (1 lag) & 0.000 & 0.000 & 0.000 & 0.000 & 0.000 & 0.000 & 0.000 & 0.000 & 0.000 \\
\hline \multicolumn{2}{|c|}{ Var. Ratio Test ( $p$-value) } & 0.000 & 0.000 & 0.000 & 0.622 & 0.826 & 0.993 & 0.999 & 0.993 & 0.999 \\
\hline \multicolumn{2}{|c|}{ J-statistic ( $p$-value) } & 0.970 & 0.556 & 0.569 & 0.728 & 0.615 & 0.824 & 0.769 & 0.120 & 0.021 \\
\hline
\end{tabular}

Period: 2000 - 2012; Cities: 29; Observations: 377

Instruments: Manufacturing, Manufacturing Exports, Pop. Density, Trend, UNESCO, Legal Area, Central Municipality Office, Period on Top, Growth 5 Years, City Brand Index.

*** Significant at $1 \%$; ** Significant at $5 \%$; *Significant at $10 \%$ Standard errors in italics and immediately under the corresponding parameter.

Kolmogorov-Smirnov is the p-value of the test: $\mathrm{H}_{0}$ : the residuals are normal $\left(0, \sigma^{2}\right)$; Q-Stat is the p-value of the test $\mathrm{H}_{0}$ : the residuals do not have one lag temporal correlation

Variance Ratio Test. $\mathrm{H}_{0}$ : residuals are a martingale; J-statistic is the p-value of the Sargan test, with $\mathrm{H}_{0}$ : the over-identified specification is correct.

Highrises: the dependent variable is the number of buildings with 100 metres or more.

Exc. Height: the dependent variable is (height of tallest building/average height of all the highrises).

2 years lag: the variables GDP, Area and GaWC are two-years lags of the corresponding contemporaneous variables. 
According to the p-value of the Sargan test (J-statistic) we never reject the null hypothesis that over-identifying restrictions are adequately specified in all of the models. In Table 5, GDP tends to perform relatively poorly, when compared with Tables 3 and 4, and its impact is even negative in model IV6. In contrast, Area performs well in all of the models of Table 5, being always negative and significant.

Period performed well in model IV3 but not in the preferred model IV6, while Cycle was rejected in all of the models. GaWC was again positive and significant in all of the models where it was included. We can infer that the GaWC index tends to control GDP and all the other theory variables, regardless the use of instruments for all of them. This means that the degree of connectivity with global flows of resources, people, and ideas is the stronger determinant of taller record breaking buildings in the Latin American region.

The results then, provide interesting insights into the determining factors behind building height in Latin American cities, discussed further in the next section. We would not wish to overstate the findings. Our results have some limitations as to scope because, as explained above, we have not been able to use a formal fixed or random effects specification. This issue might be determining over- or under-estimations of the residuals, a non-solvable estimation problem, regardless of their behaviour as a Martingale.

Furthermore, we were not able to use fixed effects in the first place because of the pure crosssection character of some variables, the pure time-series character of trend, and the national time-series character of Cycle. These limitations might be overcome with access to improved information sources, or by making a pure cross-section analysis. In the latter case, we would have to extend the database to cities out of the Latin American region and, at the same time would be unable to test the time-oriented business cycle and game theoretic model predictions.

In future research activities about this subject we might then try to extend our analysis to a wider set of cities, and emphasizing the contest between traditional theory and global cities variables. This type of analysis will also require a formal theoretical structure to be tested, where it will be clear the role of building height as a real estate asset and as a symbol for both investors and developers. That would be a type of theoretical development and testing closer to Barr (2013). 
The use of different estimation techniques in a panel context constitutes exploratory research, because, regardless of the IV estimation and time trend correction, the order of causality is still undetermined. In particular, we can be certain that GaWC index and taller record breaking buildings are associated in the Latin American region. However, we still are not sure whether a higher global ranking drives taller buildings, or the opposite: cities with taller buildings attract global sectors. The former seems more plausible but is not proved by the analysis.

In the next section we discuss these econometric results and their possible causes and implications. We will argue that, in spite of the information limitations and estimation problems, the results reflect some of the urbanization trends in the region. In particular, a skyscraper boom is expected in the region in the foreseeable future, a yet non-explored challenge for urban research and policy.

\subsection{Alternative specifications: time lag, highrises and excess height}

The alternative regressions for the equations 4,5 and 6 of section 3.2, are reported in the last three columns of tables 3, 4 and 5. The first one of these is a two-year lag of the variables GDP, Area and GaWC, selected because of its better Akaike and Schwartz criteria when compared to one and three years lags. The results replicate the findings in our preferred models Pool 6, FML 6 and IV 6, where Global cities is a strong predictor, traditional theory is a weak predictor, while cycle and period are not predictors of the top buildings' height

The second alternative regression shows the results when the dependent variable is the number of high rises, where it is not possible to use building controls and period in the regression. The reason for not using these variables is that we are not dealing with an individual building and its characteristics of location and land use. From tables 3, 4 and 5, we can appreciate that only the time trend and global cities are determinants of high rises. This is a surprising result, as we expected it to be determined by traditional theory variables.

It might be that the city controls are effective in determining high rises even more than for top height. This could be true, noting that Population HH was negative and significant in Table 5. The positive and significant effect of global cities adds to its importance in all of the above results. 
In our third alternative regression, excess height is the dependent variable. We can see in tables 3, 4 and 5 that the results are similar to our preferred Pool 6, FML6 and IV6, in particular, GaWC is once again a strong predictor although GDP is not significant. This last result is due to the fact that excess height is independent of the total building height; there can be a great excess height in cities with low averages even when the top buildings are not so tall; the opposite occurs if the average is high even if the tallest building is very tall.

As a summary of the OLS, FML and IV results, we conclude that globalization is the most evident determinant of top building height in Latin America, a force that can be enhanced or reduced, but not modified, by the economic and geographic conditions of the corresponding city. Planning via conservation (Unesco) or proxied by concentration of decision-making power (Population H-H), has a negative effect, while the cycle and game theoretic approaches are not determinants.

\section{IMPLICATIONS FOR LATIN AMERICA: THEORIES AND GEOGRAPHY}

Skyscrapers are more than simply iconic representations of urban development: they play an important role in the economies of cities. This paper has attempted to model the forces that drive the height of the tallest buildings to test the extent to which standard urban economic models provide an adequate explanation of building height or whether specific theories relating skyscrapers provide additional power in explaining the production of tall buildings.

The results presented so far depict a picture where GDP performs well in most specifications, as a predictor of building heights. This makes sense since taller buildings in the sample are located in the larger cities, the only exception being Panama City, a relatively small urban economy ${ }^{16}$. In fact, Panama has a much higher GaWC index than expected from its economic size, and this is also the case of cities like Curitiba (Brazil) or Monterrey (Mexico) (Consoni and Taylor, 2007), with relatively tall buildings relative to their size. We consider that cases like these are the reason why GDP is controlled by GaWC in some of the specifications.

It is also worth mentioning that large but geographically extended cities, like Buenos Aires and Sao Paulo, have tended to report lower building heights than Mexico City, which is economically

16 Albeit one strongly influenced by its offshore financial role. 
comparable but more compact. A similar observation can be made for extended Santiago and comparable but compact Bogota and Caracas. We think that the econometric results are capturing these characteristics with correct signs and significance for Area, consistent with traditional urban economic theory. The value of the traditional theory contrasts to early observations by Gottman as surveyed by Ford (2010), who argued that Latin American cities did not have the scarcity of land that pushed up rents and heights in a more traditional high building process like New York (Barr, 2010) or GDP-driven in the USA, Canada, China and Hong Kong (Barr et al., 2015)

The processes by which the tallest building in a city is surpassed have not been steady during the period: in fact, in 12 cities there was no replacement at all over the study period, while seven cities had only one change in the highest building. It is this characteristic that has caused temporal correlation in all of the regression results, and any correction using autoregressive components tends to perfectly predict top heights by their past realizations. This lack of replacement might also be the cause for the lack of explanatory power of the H-S game theory (and, to a lesser extent, the business cycle). This is in contradiction to the findings of Barr (2012 and 2013), where strategic height moves were found for New York, and for a competition between New York and Chicago.

However, the next few years are likely to see new building records that could alter these results. New extreme heights are being reached in many of the cities, while other cities like Fortaleza and Recife (Brazil), Tijuana and Ciudad Juarez (Mexico), and Barranquilla (Colombia), will have new high-rises and tallest buildings that would qualify them for incorporation in this type of analysis. It could be argued that, with income growth (allied to distributional inequality) in these societies, the opportunities for diverting resources towards "ego-building" might increase. It also could be that the agents, who have been painfully hit by past economic crises, are getting used to new more stable and wealthier conditions, and business cycle-driven record breaking might occur.

The impact of the degree of globalisation of these cities on building height might also become even more important in the forthcoming years. That could be the case of regions with a strong international character like the axis Buenos Aires - Sao Paulo, the Caribbean, or the northern border of Mexico, as currently observed in developing countries with stronger global ambitions like China (Kim, 2014), Turkey (Oktem, 2011) or Russia (Ford, 2008). Latin America has yet 
unsolved transition problems which might be worsened by the set of urban and socio-economic challenges associated with this global city development trend (Hamnett, 2012).

The superposition of old development problems and new global city challenges has been relatively unexplored in the literature, even though more tall projects are currently under construction on the continent. These buildings are not included in the present paper, but the number of buildings 200 meters tall or more will double in the region by 2020. They are representative of the urban transformations that globalization is bringing to these relatively traditionalist societies.

Among these buildings we highlight:

- A new continental record to be set in Santiago de Chile (300 meters) in 2014.

- The new Brazilian record (240 meters), an exotic project to be undertaken in the small resort-city of Balneario Camboriu in 2016.

- Colombia will have a new record (260 meters) by the end of 2016, another curious development as it is the largest 'crowd-funded' real estate project in the world.

- Already under construction, a skyscraper race seems to be developing in Mexico City, with a new 2015 record to be reached at 234 meters, then 237 meters in 2017, and finally 246 meters in 2018.

- The Mexican record breaker (276 meters) however, will be completed in 2016 in San Pedro Garza Garcia, a peripheral municipality of Monterrey, the third metropolitan area of this country.

- A new record for Argentina (235 meters) to be set in Buenos Aires in 2016.

- Centro Financiero Corfinanzas is an unfinished 190 meters tall building in Caracas. It is the world's tallest slum with 50,000 squatters that invaded it after the recession of 19992001 bankrupted its main investor.

- In Santos (Brazil) is located the tallest cemetery in the world. The Memorial Necrópole Ecumenica 2 was completed in 2008 and with 32 floors (108 meters) it is the tallest built structure in this city.

While some of these developments can be explained within standard urban economic paradigms, these developments, particularly in smaller or more peripheral cities, may be more appropriately explained using models that have some behavioural core. 


\section{CONCLUSIONS}

Traditional microeconomics has been used to support many research agendas, including questions about the height of very tall buildings. However, skyscrapers height looks excessive when predicted by variables extracted from microeconomic urban theories. This paper analyses three alternatives: a business cycle/behavioural perspective that relates peak moments overconfidence to new height records, game theory that uses strategic behaviour and includes an ego effect in this architectural style; and global cities, where skyscrapers would be the preferred architectural setting for the leading global-oriented economic sectors.

We estimated a panel of 29 cities from ten different countries in the period $2000-2012$, comprising 64 different record breaker buildings. We used different specifications in order to analyse the theoretically-expected relationships between building height and the variables extracted from these theories.

Because of autocorrelation problems, we used FML in addition to the OLS estimations, and because of short period problems we also used a truncated estimation process. We dealt with possible endogenous variables by using IV estimations. We found that the traditional theory variables, in particular the urban Area, are a good predictor of top height buildings. However, when using a Global Cities variable extracted from the GaWC index, the GDP performed less well. This global cities variable also proved to be strongly and positively correlated with heights in all specifications and estimation techniques. The H-S game theory and business cycle variables seemed to be poor predictors in most of the specifications, and regardless of estimation techniques. The results hold when using the alternative dependent variables: number of high rises and excess height of the tallest building in relation to the average height. They also hold when using two-year lagged realizations of the GDP, Area and GaWC.

These results are instructive in suggesting that formal urban economic models retain explanatory power but need to be augmented with considerations of the integration of cities into global economic networks. However, we have been limited in these analyses by the availability of information, and there is room for improvement in the future, in order to produce more robust results in subsequent research activities in the area. Regardless of these limitations, we consider 
that the econometric results reflect current patterns of high-rise development in the cities of the continent.

The future development of tall buildings is going to accelerate in the Latin American region, a yet unexplored opportunity for urban research, and a major challenge to urban policy. The addition of new building records to our database might alter the econometric results, and the widening of our database to other developing countries' cities is also a desirable research path, particularly because of the globally emerging character of many cities located in these countries.

\section{REFERENCES}

Anas, A; R. Arnot and K. Small (1998), Urban spatial structure. Journal of Economic Literature 36 $-3,1426-1464$.

Barr, J. (2010), Skyscrapers and the skyline: Manhattan 1895 - 2004. Real Estate Economics 38 - 3, 567-597.

Barr, J. (2012), Skyscraper height. The Journal of Real Estate Finance and Economics 43 - 1,2, 131.

Barr, J. (2013), Skyscrapers and Skylines: New York and Chicago, 1885-2007. Journal of Regional Science $53-3,369-391$.

Barr, J.; B. Mizrach and K. Mundra (2015), Skyscraper beight and the business cycle: separating myth from reality. Applied Economics 47 - 2, 148-160.

Volume 47, Issue 2, 2015

Barras, R. (2009), Building Cycles. Growth and Instability. Wiley-Blackwell - RICS Research. Chichester UK.

Bertaud, A. and J. Brueckner (2005), Analy ring building-height restrictions: Predicted impacts and welfare costs. Regional Science and Urban Economics 35 - 2, 109-125.

Cheshire, P. and G. Derricks (2014), 'Iconic design' as deadweight loss: rent acquisition by design in the constrained London office market. SERC Discussion Paper 154. Spatial Economics Research Centre London School of Economics.

Consoni, E. and P. Taylor (2007). Gateway cities: círculos bancarios, concentración y dispersión en el ambiente urbano brasileño. Revista Eure 33 - 100, 115-133.

Ding, C. (2013), Building height restrictions, land development and economic costs. Land Use Policy 30 - 1, 485-495. 
Fainstein, S. (1992), Divided Cities: New York and London in the Contemporary World. Blackwell, Oxford.

Ford, L. (1998), Midtowns, megastructures and world cities. Geographical Review 88 - 4, 528-547.

Ford, L. (2008), World cities and global change: observations on monumentality in urban design. Eurasian Geography and Economics 49 - 3, 237-262.

Ford, L. (2010), Inspirations from the geographical review: Jean Gottmann's "Why the skyscraper?" Geographical Review 100 - 3, 304-307

Fox, S. (2007), Blue cities: encompassing governance, urban integration and economic performance. IV Urban Research Symposium, World Bank, Washington.

Greene, W. (2008), Econometric Analysis. $3^{\text {rd }}$ Edition. Prentice Hall Eds.

Greene, W. (2004), The behaviour of the maximum likelihood estimator of limited dependent variable models in the presence of fixed effects. Econometrics Journal 7 - 1, 98-119.

Hall, P. The global city. International Social Science Journal. 48 - 147, 15-23.

Hamnett, C. (2012), Urban social polarization. In: Derudder et al. (eds), International Handbook of Globalization and World Cities. Edward Elgar Publishing Ltd, Cheltenham, UK.

Helsley, R. and W. Strange (2008), A game-theoretic analysis of skyscrapers. Journal of Urban Economics 64 - 1, 49-64.

Jinhua, C. et al. (2008), Critique of a Game-Theoretic Analysis of Skyscrapers. Department of Mathematics - National University Singapore.

Kaza, G. (2010), Note: wolverines, razorbacks and skyscrapers. The Quarterly Journal of Austrian Economics 13 - 4, 74-79.

Kim, J. (2014), Making cities global: the new city development of Songdo, Yujiapu and Lingang. Planning Perspectives $29-3,329-356$.

Koster, H; J. Van Ommeren, and P. Rietveld (2013), Is the sky the limit? High-rise buildings and office rents. Journal of Economic Geography $14-1,125-153$.

Kraus, M. (2007), Monocentric cities. Arnott R. and D. McMillen (eds), A Companion to Urban Economics. Blackwell Publishing, Malden MA - Oxford.

Lizieri, C. (2009), Towers of Capital. Blackwell Publishing, London.

Lizieri, C. and K. Pain (2014), International office investment in global cities: the production of financial space and systemic risk. Regional Studies $48-3,439-455$.

Loffler, G. (2013), Tower building and stock market returns. The Journal of Financial Research 23 - 3, 413-434. 
Malpezzi, S. (2006), Cross-country patterns of urban development. In: Arnott, R. and D. McMillen (eds), A Companion to Urban Economics. Blackwell Publishing, London.

McMillen, D. (2003), The return of centralization to Chicago: using repeat sales to identify changes in house price distance gradients. Regional Science and Urban Economics 33 - 3, 287-304.

Oktem, B. (2011), The role of global city discourses in the development and transformation of the BuyukdereMaslak axis into the international business district of Istanbul. International Planning Studies 16 - 1, 2742.

Sassen, S. (1991), Cities in a world economy. 3th edition (2006), Thousand Oaks, CA. Pine Forge Press.

Shiller, R. (2005), Irrational Exuberance. Priceton University Press, NJ.

Soares, J. (2010), The environmental performance of tall buildings. Earthscan, London.

Sorensen, A. (2005), Building world city Tokyo: globalization and conflict over urban space. Richardson, H. and C. Bae (eds), Globalization and Urban Development. Springer-Verlag, Berlin.

Thornton, M. (2005), Skyscrapers and business cycles. The Quarterly Journal of Austrian Economics $8-1,51-74$. 


\section{APPENDIX}

Appendix: Top Height per City (in metres)

\begin{tabular}{|c|c|c|c|c|c|c|c|c|c|c|c|c|c|c|}
\hline Country & City & 2000 & 2001 & 2002 & 2003 & 2004 & 2005 & 2006 & 2007 & 2008 & 2009 & 2010 & 2011 & 2012 \\
\hline Argentina & Buenos Aires & 158 & 158 & 158 & 160 & 160 & 160 & 160 & 160 & 160 & 173 & 173 & 173 & 173 \\
\hline Argentina & Rosario & 71 & 71 & 115 & 115 & 115 & 115 & 115 & 115 & 115 & 125 & 137 & 137 & 137 \\
\hline Argentina & Mar del Plata & 125 & 125 & 125 & 125 & 125 & 125 & 125 & 125 & 125 & 125 & 125 & 125 & 125 \\
\hline Bolivia & La Paz & 130 & 130 & 130 & 130 & 130 & 130 & 130 & 130 & 130 & 130 & 130 & 130 & 130 \\
\hline Brazil & Sao Paulo & 170 & 170 & 170 & 170 & 170 & 170 & 170 & 170 & 170 & 170 & 170 & 170 & 170 \\
\hline Brazil & Rio de Janeiro & 168 & 168 & 168 & 168 & 168 & 168 & 168 & 168 & 168 & 168 & 168 & 168 & 168 \\
\hline Brazil & Salvador & 112 & 112 & 112 & 112 & 112 & 115 & 115 & 115 & 155 & 155 & 155 & 155 & 155 \\
\hline Brazil & Curitiba & 124 & 124 & 124 & 124 & 137 & 137 & 137 & 137 & 137 & 137 & 137 & 137 & 137 \\
\hline Brazil & Brasilia & 101 & 101 & 101 & 101 & 101 & 101 & 101 & 101 & 101 & 102 & 102 & 120 & 120 \\
\hline Brazil & Porto Alegre & 119 & 119 & 119 & 119 & 119 & 119 & 119 & 119 & 119 & 119 & 119 & 119 & 119 \\
\hline Brazil & Cuiaba (MT) & 103 & 103 & 103 & 103 & 103 & 103 & 108 & 108 & 108 & 108 & 108 & 108 & 108 \\
\hline Brazil & Belo Horizonte & 101 & 101 & 101 & 101 & 101 & 101 & 101 & 101 & 104 & 104 & 104 & 104 & 104 \\
\hline Chile & Santiago & 142 & 142 & 142 & 142 & 142 & 142 & 142 & 142 & 142 & 142 & 194 & 194 & 194 \\
\hline Colombia & Bogota & 196 & 196 & 196 & 196 & 196 & 196 & 196 & 196 & 196 & 196 & 196 & 196 & 196 \\
\hline Colombia & Cali & 183 & 183 & 183 & 183 & 183 & 183 & 183 & 183 & 183 & 183 & 183 & 183 & 183 \\
\hline Colombia & Cartagena & 70 & 70 & 70 & 70 & 70 & 70 & 75 & 116 & 160 & 160 & 170 & 170 & 170 \\
\hline Colombia & Medellin & 160 & 160 & 160 & 160 & 160 & 160 & 160 & 160 & 160 & 160 & 160 & 160 & 160 \\
\hline Ecuador & Guayaquil & 135 & 135 & 135 & 135 & 135 & 135 & 135 & 135 & 135 & 135 & 135 & 135 & 135 \\
\hline Mexico & Mexico City & 211 & 211 & 211 & 225 & 225 & 225 & 225 & 225 & 225 & 225 & 225 & 225 & 225 \\
\hline Mexico & Guadalajara & 95 & 95 & 95 & 95 & 95 & 110 & 110 & 172 & 172 & 172 & 172 & 189 & 189 \\
\hline Mexico & Monterrey & 167 & 167 & 167 & 167 & 167 & 167 & 167 & 167 & 167 & 167 & 180 & 180 & 180 \\
\hline Mexico & Mazatlan & 65 & 65 & 65 & 65 & 65 & 65 & 65 & 79 & 79 & 106 & 112 & 143 & 143 \\
\hline Mexico & Acapulco & 123 & 123 & 123 & 123 & 123 & 123 & 123 & 123 & 123 & 123 & 123 & 123 & 123 \\
\hline Mexico & Puebla & 74 & 74 & 74 & 74 & 74 & 94 & 94 & 94 & 123 & 123 & 123 & 123 & 123 \\
\hline Mexico & Puerto Vallarta & 75 & 75 & 75 & 75 & 75 & 75 & 75 & 104 & 104 & 110 & 110 & 110 & 110 \\
\hline Panama & Panama City & 172 & 172 & 172 & 172 & 172 & 176 & 176 & 210 & 210 & 210 & 273 & 284 & 284 \\
\hline Peru & Lima & 132 & 132 & 132 & 132 & 132 & 132 & 132 & 132 & 132 & 132 & 132 & 165 & 165 \\
\hline Venezuela & Caracas & 225 & 225 & 225 & 225 & 225 & 225 & 225 & 225 & 225 & 225 & 225 & 225 & 225 \\
\hline Venezuela & Maracay & 125 & 125 & 125 & 125 & 125 & 125 & 125 & 125 & 125 & 125 & 125 & 125 & 125 \\
\hline
\end{tabular}

